\title{
Front Matter: Volume 8964
}

, "Front Matter: Volume 8964," Proc. SPIE 8964, Nonlinear Frequency Generation and Conversion: Materials, Devices, and Applications XIII, 896401 (25 February 2014); doi: 10.1117/12.2062797

SPIE. Event: SPIE LASE, 2014, San Francisco, California, United States 


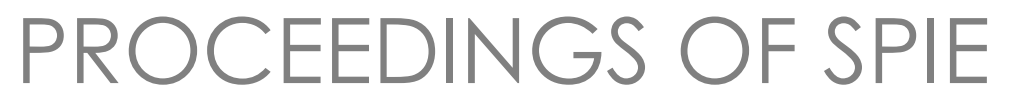

\section{Nonlinear Frequency Generation and Conversion: Materials, Devices, and Applications XIII}

Konstantin L. Vodopyanov

Editor

4-6 February 2014

San Francisco, California, United States

Sponsored and Published by

SPIE 
The papers included in this volume were part of the technical conference cited on the cover and title page. Papers were selected and subject to review by the editors and conference program committee. Some conference presentations may not be available for publication. The papers published in these proceedings reflect the work and thoughts of the authors and are published herein as submitted. The publisher is not responsible for the validity of the information or for any outcomes resulting from reliance thereon.

Please use the following format to cite material from this book:

Author(s), "Title of Paper," in Nonlinear Frequency Generation and Conversion: Materials, Devices, and Applications XIII, edited by Konstantin L. Vodopyanov, Proceedings of SPIE Vol. 8964 (SPIE, Bellingham, WA, 2014) Article CID Number.

ISSN: 0277-786X

ISBN: 9780819498779

Published by

SPIE

P.O. Box 10, Bellingham, Washington 98227-0010 USA

Telephone +1 3606763290 (Pacific Time) · Fax +1 3606471445

SPIE.org

Copyright (c) 2014, Society of Photo-Optical Instrumentation Engineers.

Copying of material in this book for internal or personal use, or for the internal or personal use of specific clients, beyond the fair use provisions granted by the U.S. Copyright Law is authorized by SPIE subject to payment of copying fees. The Transactional Reporting Service base fee for this volume is $\$ 18.00$ per article (or portion thereof), which should be paid directly to the Copyright Clearance Center (CCC), 222 Rosewood Drive, Danvers, MA 01923. Payment may also be made electronically through CCC Online at copyright.com. Other copying for republication, resale, advertising or promotion, or any form of systematic or multiple reproduction of any material in this book is prohibited except with permission in writing from the publisher. The CCC fee code is 0277-786X/14/\$18.00.

Printed in the United States of America.

Publication of record for individual papers is online in the SPIE Digital Library.

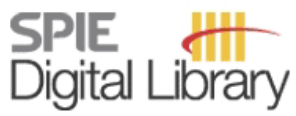

SPIEDigitalLibrary.org

Paper Numbering: Proceedings of SPIE follow an e-First publication model, with papers published first online and then in print and on CD-ROM. Papers are published as they are submitted and meet publication criteria. A unique, consistent, permanent citation identifier (CID) number is assigned to each article at the time of the first publication. Utilization of CIDs allows articles to be fully citable as soon as they are published online, and connects the same identifier to all online, print, and electronic versions of the publication. SPIE uses a six-digit CID article numbering system in which:

- The first four digits correspond to the SPIE volume number.

- The last two digits indicate publication order within the volume using a Base 36 numbering

system employing both numerals and letters. These two-number sets start with 00, 01, 02, 03, 04, $05,06,07,08,09,0 A, 0 B \ldots$. 0Z, followed by 10-1Z, 20-2Z, etc.

The CID Number appears on each page of the manuscript. The complete citation is used on the first page, and an abbreviated version on subsequent pages. Numbers in the index correspond to the last two digits of the six-digit CID Number. 


\section{Contents}

ix Conference Committee

VISIBLE AND UV SOURCES BASED ON NONLINEAR CONVERSION

$896402 \mathrm{CW}$ emission at $193 \mathrm{~nm}$ using an all solid-state laser source (Invited Paper) [8964-1] M. Scholz, D. Opalevs, J. Stuhler, P. Leisching, W. Kaenders, TOPTICA Photonics AG (Germany); G. Wang, X. Wang, R. Li, C. Chen, Beijing Ctr. for Crystal Research and Development (China)

896403 High power green, yellow, and UV fiber lasers (Invited Paper) [8964-2]

E. Tal, E. E. Rowen, D. Barness, J. Lasri, E. Inbar, V-Gen Ltd. (Israel)

896404 A new approach to sum frequency generation of single-frequency blue light in a coupled ring cavity [8964-3]

O. B. Jensen, P. M. Petersen, Technical Univ. of Denmark (Denmark)

896405 Efficient generation of orange light by frequency-doubling of a quantum-dot laser radiation in a PPKTP waveguide [8964-4]

K. A. Fedorova, Univ. of Dundee (United Kingdom); G. S. Sokolovskii, loffe Physico-Technical Institute (Russian Federation), Univ. of Dundee (United Kingdom), and St. Petersburg State Electrotechnical Univ. (Russian Federation); P. R. Battle, AdvR, Inc. (United States);

D. A. Livshits, Innolume GmbH (Germany); E. U. Rafailov, Univ. of Dundee (United Kingdom)

896406 Generation of $3.5 \mathrm{~W}$ of diffraction-limited green light from SHG of a single tapered diode laser in a cascade of nonlinear crystals [8964-5]

A. K. Hansen, O. B. Jensen, Technical Univ. of Denmark (Denmark); B. Sumpf, G. Erbert, Ferdinand-Braun-Institut (Germany); A. Unterhuber, W. Drexler, Medizinische Univ. Wien (Austria); P. E. Andersen, P. M. Petersen, Technical Univ. of Denmark (Denmark)

896407 SM green fiber laser operating in CW and QCW regimes and producing over $550 \mathrm{~W}$ of average output power [8964-70]

V. Gapontsev, A. Avdokhin, P. Kadwani, I. Samartsev, N. Platonov, R. Yagodkin, IPG

Photonics Corp. (United States)

\section{PHOTONIC TERAHERTZ GENERATION}

896408 Continuous-wave optical parametric source for terahertz waves tunable from 1 to $4.5 \mathrm{THz}$ frequency (Invited Paper) [8964-6]

J. Kießling, Fraunhofer-Institut für Physikalische Messtechnik (Germany); K. Buse, FraunhoferInstitut für Physikalische Messtechnik (Germany) and Univ. Freiburg (Germany);

K. L. Vodopyanov, CREOL, The College of Optics and Photonics, Univ. of Central Florida (United States); I. Breunig, Univ. Freiburg (Germany) 
896409 Ultra-broadband IR and THz generation and detection with ultrashort pulses (Invited Paper) [8964-7]

M. Ashida, E. Matsubara, Osaka Univ. (Japan); I. Katayama, Yokohama National Univ. (Japan)

8964 OB Room temperature terahertz wave imaging at $60 \mathrm{fps}$ by frequency up-conversion in DAST crystal [8964-9]

S. Fan, F. Qi, T. Notake, K. Nawata, T. Matsukawa, Y. Takida, H. Minamide, RIKEN (Japan)

\section{OPTICAL PARAMETRIC AND ULTRAFAST NONLINEAR DEVICES}

8964 OD Efficient femtosecond 50-MHz repetition rate mid-IR source up to $17 \mu \mathrm{m}$ by differencefrequency generation in AgGaSe 2 [8964-1 1]

M. Beutler, I. Rimke, E. Büttner, APE GmbH (Germany); V. Badikov, D. Badikov, Kuban State Univ. (Russian Federation); V. Petrov, Max-Born-Institut für Nichtlineare Optik und Kurzzeitspektroskopie (Germany)

8964 OF Non-collinear upconversion of incoherent light: designing infrared spectrometers and imaging systems [8964-13]

J. S. Dam, Q. Hu, C. Pedersen, P. Tidemand-Lichtenberg, Technical Univ. of Denmark (Denmark)

\section{NONLINEAR OPTICAL PHENOMENA AND SIGNAL PROCESSING}

8964 OL All-optical signal regeneration of advanced modulation formats (Invited Paper) [8964-19] T. Roethlingshoefer, Max-Planck-Institut für die Physik des Lichts (Germany) and FriedrichAlexander Univ. Erlangen-Nürnberg (Germany); T. Richter, Fraunhofer-Institut für Nachrichtentechnik Heinrich-Hertz-Institut (Germany); B. Stiller, G. Onishchukov, MaxPlanck-Institut für die Physik des Lichts (Germany) and Friedrich-Alexander Univ. ErlangenNürnberg (Germany); C. Schubert, Fraunhofer-Institut für Nachrichtentechnik HeinrichHertz-Institut (Germany); B. Schmauss, Friedrich-Alexander-Univ. Erlangen-Nürnberg (Germany); G. Leuchs, Max-Planck-Institut für die Physik des Lichts (Germany) and Friedrich-Alexander-Univ. Erlangen-Nürnberg (Germany)

8964 OM Generation of low-noise frequency replicas in parametric frequency combs via phasesensitive process (Invited Paper) [8964-20]

Z. Tong, L. Liu, S. Radic, Univ. of California, San Diego (United States)

$8964 \mathrm{ON}$ Mode-selective frequency up-conversion in a $X^{(2)}$ waveguide [8964-21]

Y. B. Kwon, M. Vasilyev, The Univ. of Texas at Arlington (United States) 
$8964 \mathrm{OP}$ Influence of pump fiber laser conditions at $1550 \mathrm{~nm}$ on broadband infrared supercontinuum generation in all-solid all-normal dispersion photonic crystal fibers [8964-23]

M. Klimczak, Institute of Electronic Materials Technology (Poland); B. Siwicki, Institute of Electronic Materials Technology (Poland) and Univ. of Warsaw (Poland); G. Soboń, J. Sotor, Wroclaw Univ. of Technology (Poland); D. Pysz, R. Stępień, Institute of Electronic Materials Technology (Poland); T. Martynkien, K. Abramski, Wroclaw Univ. of Technology (Poland); R. Buczyński, Institute of Electronic Materials Technology (Poland) and Univ. of Warsaw (Poland)

$89640 Q \quad$ Fiber laser driven dual photonic crystal fiber femtosecond mid-infrared source tunable in the range of 4.2 to $9 \mu \mathrm{m}$ [8964-24]

Y. Yao, W. H. Knox, Univ. of Rochester (United States)

8964 OR Investigations of SBS and laser gain competition in high-power phase modulated fiber amplifiers [8964-25]

A. Flores, I. Dajani, Air Force Research Lab. (United States); D. Hult, Trex Enterprises Corp. (United States); C. Robin, Air Force Research Lab. (United States)

\section{FREQUENCY COMBS AND SUPERCONTINUUM GENERATION}

8964 OV Broadband IR supercontinuum generation in hexagonal lattice tellurite photonic crystal fiber with dispersion optimized for pumping over $1500 \mathrm{~nm}$ [8964-29]

M. Klimczak, Institute of Electronic Materials Technology (Poland); G. Stępniewski, Institute of Electronic Materials Technology (Poland) and Univ. of Warsaw (Poland); H. Bookey, Heriot-Watt Univ. (United Kingdom) and Fraunhofer Ctr. for Applied Photonics (United Kingdom); D. Pysz, Institute of Electronic Materials Technology (Poland); A. Waddie, HeriotWatt Univ. (United Kingdom); R. Stępień, Institute of Electronic Materials Technology (Poland); A. Kar, M. R. Taghizadeh, Heriot-Watt Univ. (United Kingdom); R. Buczyński, Institute of Electronic Materials Technology (Poland) and Univ. of Warsaw (Poland)

8964 0X Mid-infrared supercontinuum generation using lead-bismuth-gallium-oxide glass-based photonic crystal fibers pumped at $1560 \mathrm{~nm}$ [8964-31] G. Soboń, Wroclaw Univ. of Technology (Poland); M. Klimczak, Institute of Electronic Materials Technology (Poland); J. Sotor, K. Krzempek, Wroclaw Univ. of Technology (Poland); D. Pysz, R. Stępień, Institute of Electronic Materials Technology (Poland); T. Martynkien, G. Dudzik, K. M. Abramski, Wroclaw Univ. of Technology (Poland); R. Buczynski, Institute of Electronic Materials Technology (Poland) and Univ. of Warsaw (Poland)

8964 OY Mid-infrared frequency comb generation using a continuous-wave pumped optical parametric oscillator [8964-69]

M. Vainio, Univ. of Helsinki (Finland) and Ctr. for Metrology and Accreditation (Finland); V. Ulvila, Univ. of Helsinki (Finland); C. R. Phillips, ETH Zürich (Switzerland); L. Halonen, Univ. of Helsinki (Finland) 
896410 Sensitive absorption measurements in bulk material and coatings using a photothermal and a photoacoustic spectrometer [8964-33]

S. Fieberg, N. Waasem, F. Kühnemann, Fraunhofer-Institut für Physikalische Messtechnik (Germany); K. Buse, Fraunhofer-Institut für Physikalische Messtechnik (Germany) and Univ. Freiburg (Germany)

\section{NONLINEAR MATERIALS AND CHARACTERIZATION II}

896417 Laser damage studies of $\mathrm{CdSiP}_{2}$ and $\mathrm{ZnGeP}_{2}$ nonlinear crystals with nanosecond pulses at 1064 and $2090 \mathrm{~nm}$ [8964-41]

A. Hildenbrand, C. Kieleck, Institut Franco-Allemand de Recherches de Saint-Louis (France); A. Tyazhev, G. Marchev, Max-Born-Institut für Nichtlineare Optik und Kurzzeitspektroskopie (Germany); G. Stöppler, M. Eichhorn, Institut Franco-Allemand de Recherches de Saint-Louis (France); P. Schunemann, BAE Systems (United States); V. Petrov, Max-Born-Institut für Nichtlineare Optik und Kurzzeitspektroskopie (Germany)

896418 Estimation of random duty-cycle error in periodically poled lithium niobate by simple diffraction experiment [8964-42]

P. P. Dwivedi, H. J. Choi, B. J. Kim, M. Cha, Pusan National Univ. (Korea, Republic of)

896419 Measurement of thermal lensing in GaAs induced by 100 W Tm:fiber laser [8964-43] J. Bradford, K. Vodopyanov, CREOL, The College of Optics and Photonics, Univ. of Central Florida (United States); P. Schunemann, BAE Systems (United States); L. Shah, M. Richardson, CREOL, The College of Optics and Photonics, Univ. of Central Florida (United States)

\section{POSTER SESSION}

8964 1A Multicolor frequency upconversion luminescence in europium/terbium co-doped ytterbium-sensitized fluorogermanate glass excited at $980 \mathrm{~nm}$ [8964-44]

J. R. Silva, A. S. Gouveia-Neto, L. A. Bueno, Univ. Federal Rural de Pernambuco (Brazil)

8964 1B Expanding frequency comb by means of enhanced multiple four-wave mixing [8964-45] S. A. S. Melo, INATEL (Brazil); A. R. do Nascimento Jr., Univ. Estadual de Campinas (Brazil); A. Cerqueira S. Jr., INATEL (Brazil); L. H. H. Carvalho, D. M. Pataca, J. C. R. F. Oliveira, CpqD Foundation (Brazil)

8964 1C New simple method for measuring nonlinear polarization ellipse rotation with high precision using a dual-phase lock-in [8964-46]

M. L. Miguez, E. C. Barbano, S. C. Zilio, L. Misoguti, Univ. de São Paulo (Brazil)

$89641 G$ Sum frequency generation process for a new astronomical instrument [8964-51]

R. Baudoin, Xlim, CNRS, Univ. de Limoges (France) and Leukos Ester Technopole (France);

J. T. Gomes, L. Delage, L. Grossard, Xlim, CNRS, Univ. de Limoges (France);

T. A. Ten Brummelar, N. J. Scott, J. Sturmann, Mount Wilson Observatory (United States);

F. Reynaud, Xlim, CNRS, Univ. de Limoges (France) 
$89641 \mathrm{H} \quad$ Upconversion enhanced degenerate four-wave mixing in the mid-infrared for sensitive detection of acetylene in gas flows [8964-52]

L. Høgstedt, J. S. Dam, Technical Univ. of Denmark (Denmark); A.-L. Sahlberg, Z. Li, M. Aldén, Lund Univ. (Sweden); C. Pedersen, P. Tidemand-Lichtenberg, Technical Univ. of Denmark (Denmark)

8964 1K Mid-infrared upconversion spectroscopy using diffuse reflectance [8964-55] N. Sanders, L. Kehlet, J. S am, P. Tidemand-Lichtenberg, Technical Univ. of Denmark (Denmark); P. Beato, Haldor Topsøe A/S (Denmark); C. Pedersen, Technical Univ. of Denmark (Denmark)

$89641 \mathrm{~L} \quad$ Near diffraction limited mid-IR spectromicroscopy using frequency upconversion [8964-56] N. Sanders, J. S. Dam, P. Tidemand-Lichtenberg, C. Pedersen, Technical Univ. of Denmark (Denmark)

$89641 \mathrm{M}$ Saturable absorption properties of multi-core nonlinear fiber arrays [8964-57] E. Nazemosadat, A. Mafi, Univ. of Wisconsin-Milwaukee (United States)

896410 High energy $\mathrm{Yb}: \mathrm{CaF}_{2}$ femtosecond laser for efficient terahertz generation in lithium niobate [8964-59]

C. Vicario, Paul Scherrer Institut (Switzerland); B. Monoszlai, Paul Scherrer Institut (Switzerland) and Univ. of Pécs (Hungary); Cs. Lombosi, Univ. of Pécs (Hungary); A. Mareczko, A. Courjaud, Amplitude Systèmes (France); J. A. Fülöp, MTA-PTE High-Field Terahertz Research Group (Hungary) and ELI-Hu Nkft. (Hungary); C. P. Hauri, Paul Scherrer Institut (Switzerland) and Ecole Polytechnique Fédérale de Lausanne (Switzerland)

8964 IP Continuously tunable, from $\mathrm{MHz}$ to $\mathrm{GHz}$ range, pulse train generation and its dynamic properties [8964-60]

X. You, Télécom ParisTech (France); G. G. Perez-Sanchez, IPN (Mexico); C. Gosset, Télécom ParisTech (France)

$89641 Q \quad$ Enhanced second harmonic generation in lithium niobate hexagonal micro-resonator via total internal reflection quasi-phase-matching [8964-61]

C. Riziotis, National Hellenic Research Foundation (Greece); T. J. Sono, Element Six (Pty) Ltd. (South Africa); S. Mailis, R. W. Eason, Univ. of Southampton (United Kingdom)

$89641 \mathrm{U}$ Difference frequency generation of mid-IR radiation in PPLN crystals using a dualwavelength all-fiber amplifier [8964-65]

K. Krzempek, G. Soboń, G. Dudzik, J. Sotor, K. M. Abramski, Wroclaw Univ. of Technology (Poland)

$89641 \mathrm{~W}$ Theoretical analysis of effect of pump and signal wavelengths on modal instabilities in Ybdoped fiber amplifiers [8964-67]

S. Naderi, Ball Aerospace \& Technologies Corp. (Mexico); I. Dajani, J. Grosek, T. Madden, Air Force Research Lab. (United States); T.-N. Dinh, Univ. of Delaware (United States)

$89641 X \quad$ Pump suppressed four-wave mixing in optical fibers for correlated photon generation using feedback technique [8964-68]

A. Jain, Suchita, K. P.Kumar, R. Vijaya, Indian Institute of Technology Kanpur (India)

Author Index 
Proc. of SPIE Vol. $8964896401-8$

Downloaded From: https://www.spiedigitallibrary.org/conference-proceedings-of-spie on 26 Apr 2023 Terms of Use: https://www.spiedigitallibrary.org/terms-of-use 


\title{
Conference Committee
}

\author{
Symposium Chairs \\ Bo Gu, Bos Photonics (United States) \\ Andreas Tünnermann, Fraunhofer-Institut für Angewandte Optik und \\ Feinmechanik (Germany) and Friedrich-Schiller-Universität Jena \\ (Germany) \\ Symposium Co-chairs \\ Guido Hennig, Daetwyler Graphics AG (Swtizerland) \\ Yongfeng Lu, University of Nebraska-Lincoln (United States)

\section{Conference Chair}

Konstantin L. Vodopyanov, CREOL, The College of Optics and Photonics, University of Central Florida (United States)

Conference Co-chair

Yehoshua Y. Kalisky, Nuclear Research Center Negev (Israel)

Conference Program Committee

Darrell J. Armstrong, Sandia National Laboratories (United States)

Majid Ebrahim-Zadeh, ICFO - Institut de Ciències Fotòniques (Spain)

Peter Günter, ETH Zurich (Switzerland)

Baldemar Ibarra-Escamilla, Instituto Nacional de Astrofísica, Óptica y

Electrónica (Mexico)

Moti Katz, Soreq Nuclear Research Center (Israel)

Yun-Shik Lee, Oregon State University (United States)

Rita D. Peterson, Air Force Research Laboratory (United States)

Peter E. Powers, University of Dayton (United States)

Peter G. Schunemann, BAE Systems (United States)

Kenneth L. Schepler, Air Force Research Laboratory (United States)

Andrei V. Shchegrov, KLA-Tencor Corporation (United States)

Wei Shi, Tianjin University (China)

Michael Vasilyev, The University of Texas at Arlington (United States)

\section{Session Chairs}

1 Visible and UV Sources Based on Nonlinear Conversion

Andrei V. Shchegrov, KLA-Tencor Corporation (United States)

Yehoshua Y. Kalisky, Nuclear Research Center Negev (Israel) 
2 Photonic Terahertz Generation

Peter Günter, ETH Zurich (Switzerland)

Wei Shi, Tianjin University (China)

3 Optical Parametric and Ultrafast Nonlinear Devices

Darrell J. Armstrong, Sandia National Laboratories (United States)

$4 \quad$ High-order and Stimulated Nonlinear Phenomena

Konstantin L. Vodopyanov, CREOL, The College of Optics and Photonics, University of Central Florida (United States)

5 Nonlinear Optical Phenomena and Signal Processing Michael Vasilyev, The University of Texas at Arlington (United States)

Darrell J. Armstrong, Sandia National Laboratories (United States)

6 Nonlinear Fiber Devices and Applications

Darrell J. Armstrong, Sandia National Laboratories (United States)

Michael Vasilyev, The University of Texas at Arlington (United States)

7 Frequency Combs and Supercontinuum Generation

Konstantin L. Vodopyanov, CREOL, The College of Optics and

Photonics, University of Central Florida (United States)

8 Nonlinear Materials and Characterization I

Rita D. Peterson, Air Force Research Laboratory (United States)

9 Nonlinear Materials and Characterization II

Wei Shi, Tianjin University (China) 